\title{
A Review of the Problems and the Solutions in Middle School Oral English Teaching in China
}

\author{
Yajuan Zhang, * \\ ${ }^{1}$ School of Shanghai Normal University, Shanghai, China \\ *Corresponding author. Email: 1000459951@smail.shnu.edu.cn
}

\begin{abstract}
Economic globalization has brought people around the world closer and English has become significantly important as the key to communicate effectively with other global citizens. The globalization trend has required countries in the world to educate more future generations who have good oral English proficiency to be able to communicate effectively in all context, including China. However, Chinese students' oral English proficiency remain low in general despite the increasing demands. Thus, this paper reviews the problems and the solutions in middle school oral English teaching in China in order to shed lights on policy makers, schools, and parents on how to improve Chinese students' oral English proficiency to meet the challenges brought by the economic globalization. The problems were presented in three aspects: the problems of teaching, the problems of students and the problem of lacking speaking environment. The current research conclusions mainly focus on how teachers improve teaching methods and guide students such as: improving teaching ability, providing more opportunities for students to practice English and attaching more importance to the teaching of phonetic alphabet and phonics. Solutions on particular problems indicated are also provided in the following areas: teachers' teaching methods and teachers' supports on students. Suggestions for future development are also provided.
\end{abstract}

Keywords: Problems of Oral English Teaching, Solutions of Oral English Teaching, oral English Proficiency, English Teaching, Middle School, China.

\section{INTRODUCTION}

As an international language, English is widely used as a communication tool around the world. In China, many middle school students are still learning the "mute English", which refers to a scenario that students' oral English proficiency is lower than they actually should be. Thus, the purpose of learning English seems to be for the test on paper and students even cannot simply communicate appropriately and effectively in English. Studies on English teaching and learning in China have already indicated some problems in oral English teaching in middle schools in China. Thus, this paper aimed to review issues around the oral English teaching in middle schools in China in order to shed lights on future teacher practices. Particularly, three essential problems were discussed in this review: (1) Teachers' capacity in teaching oral English, (2) students' awareness of the importance of oral English; and (3) self-confidence and English speaking environment. According to these problems, the author lists two corresponding advices for English teachers in middle school and methods to improve students' interest and confidence. In addition, the author puts forward some suggestions for the later development of oral English teaching.

\section{PROBLEMS IN TEACHING ORAL ENGLISH TO MIDDLE SCHOOL STUDENTS IN CHINA}

\subsection{The Problems in Teaching}

Empirical studies on the problems of Chinese English teachers' teaching generally focused on three issues: (1) teachers' level of oral English proficiency; (2) frequency of providing opportunities to speak in class; and (3) awareness of the importance of teaching phonetic Alphabet and phonetic.

\subsubsection{The level of the teacher's oral English}

Scholars indicated that middle English teachers' oral English proficiency is often limited. The teaching 
quality of English teachers in junior middle schools is usually uneven, especially in oral English. According to Zhou, the limitations of English teaching are partially reflected in the teachers. First, English teachers usually are not prepared enough in their teacher education programs in regard to how to teach oral English in the actual classroom. Second, middle school teachers' oral English proficiency is not good enough to be able to teach students to communicate appropriately and effectively. The low oral English proficiency among middle school English teachers often leads to one single teaching method that is widely used: teach their students for higher test scores instead of practicing it. Therefore, students' oral English proficiency remain low over the years due to lack of practicing.

Moreover, the oral English proficiency of middle school teachers in certain underdeveloped areas in China is even below average due to a variety of reasons, as compared to other urban areas. Yu found that most of English teachers in rural middle school have lower oral English scores, and their professional skill in teaching oral English is insufficient. Specifically, they cannot speak fluent English in class, even the proper pronunciation is an issue for them. Ye further pointed out that the wrong pronunciation that has taught in class by those teachers will produce deep influence for students [2]. For example, plenty of rural English teachers cannot pronounce "c; h; j; g; w" accurately according to the author's experience. It will mislead many students and result in their worse pronunciation in the future.

\subsubsection{Insufficient Oral English Practicing in Class}

Insufficient practicing in oral English is a common phenomenon in middle schools of China. Yu held the view that there are quite a number of teachers who still use the traditional English teaching method in English teaching: they would just focus on imparting knowledge of English grammar in class, and students just passively accept what the teacher taught, so they recite the text, remember words and sentences and take notes in class. The consequences of such traditional English teaching method is: students and teachers will end up just paying attention to developing reading and writing skills and thus ignore the importance of oral English development [2]. To ensure their students to get better test scores, many teachers usually spend more time in reading and writing and less time in practicing oral English.

$\mathrm{Li}$ claimed that it is difficult for students to effectively practice oral English communication in traditional English classes, and teachers do not usually have sufficient oral English proficiency to provide appropriate oral English communication instructions to students. Therefore, middle school English teachers often ended up listing English vocabulary and grammar on the whiteboard, and the only thing the students can do is to passively listening to their teachers' instruction [3]. It is all known that practice makes perfect. If students do not have enough opportunities to comminate with others in English, their oral English proficiency will not be improved.

\subsubsection{Limited Knowledge of Phonetic Alphabet and Phonics}

A group of studies on China's middle school English teachers' oral English teaching indicated that teachers usually spend very little time on teaching phonetic alphabets and phonics. For example, Zhang argued that most teachers only complete the unit teaching tasks, while ignoring the teaching of reading phonetic symbols and the skills of spelling words. Therefore, many students do not have the skill to properly spell a world even in junior middle school, and many of them can not even reach the level 5 target standard required by the "Curriculum Standard". International phonetic alphabet and phonics are both the basis of English pronunciation, just like pinyin in Chinese [4]. If we cannot master pinyin in Chinese learning, we will encounter greater challenges in reading correctly, which will result in a poor command of speaking this kind of language. The same applies to Oral English learning. For example, students can read "examination" correctly through "/Ig,zæmi'neI $\int \mathrm{n} /$ " and they can also read this word if they knew how to pronounce every letter of examination.

Zhou's study revealed similar results. She studied the translation version of Oxford Junior Middle School English, which are widely used as the formal textbook in many provinces in China. She indicated that even though many phonetic items are set up in the book, many teachers tended to just teach the content of the textbook and skip the parts on phonetic knowledge. Thus, students' pronunciation and intonation usually are not very accurate when reading and talking [5]. As a middle school English teacher in Beijing, I have to admit that in order to quickly improve the scores of children especially in grade nine when they are going to take High School Entrance Examination, the teaching process is basically aimed at the children's vocabulary, grammar and problems solving skills. The only oral English practice is the last two parts in the Listening and Speaking test: Listening and Repeating the Passage and Short Passage Reading. These two parts do not teach phonetic alphabet and phonics, which is far from enough for most of the students to have a good command of oral English.

\subsection{The Problems in Middle School Students}

Studies on the problems Chinese's students oral English generally focused on: (1) awareness of the importance of oral English; and (2) self confidence. 


\subsubsection{Attaching little Importance to Spoken English}

Due to the influence of traditional teaching methods and examination policies (oral English is not tested in many areas in China), students do not pay much attention to their oral English development. Song claimed that in order to prepare with the high school entrance examination and college entrance examination, most students have to pay more attention to the learning of oral English. However, many students considered that oral English is useless or even unnecessary especially in some areas the oral English test scores are not included in the total test score. The students do not seem to understand the importance of oral English and they usually considered that they don't need additional oral English training [6].

\subsubsection{Lacking of Self-Confidence}

Some studies show that students usually do not have the confidence in oral English speaking mainly because they are scared of making mistakes in front of their peers and public. Song held the view that many students have a vague fear of making mistakes in front of their peers and public, being blamed by parents, and being laughed at when they speak inappropriate English. Some students' fear of oral English speaking even lead to anxiety in students' oral English communication, which seriously affecting normal communication and the normal operation of thinking [6]. Fear will sometimes lead to a blank of mind, which will have a great impact on students' language expression, making them lose confidence.

Meanwhile, according to $\mathrm{Li}$, some junior high school English learners are afraid of speaking English in class and in their daily life because of the lack of necessary self-confidence. This not only affects junior middle school students' oral English learning ability, but also affects learners' confidence in English learning to a certain extent. [7] Language learning needs a lot of practice. If students are afraid to open their mouth to express themselves for a variety of reasons, they will learn the "dumb English" and will not develop the habit of being able to express themselves confidently in English. Without the habit of speaking English with self-confidence, they will feel even less confident when they encounter sudden needs to express themselves in English.

\subsection{Lacking of Speaking Environment}

Scholars' opinions about the lack of oral English environment mainly about the lack of oral learning environment in class and after-class language environment. Zhou argued that the improvement of oral English ability cannot be separated from the influence of a good language environment. Junior high school students mainly use Chinese to communicate in daily life, and there is little time for oral English training since they only have several English classes per week [8]. If teachers do not pay enough attention the importance of purposefully develop an environment for students to practice oral English in class, students will have even less opportunities to practice English after class.

While Lv claimed that language environment is very important for language learning. For English teaching, Chinese students usually lack the necessary language environment. Chinese students learn English in the Chinese environment, and students have no chance to encounter English except in extremely limited English classes [9]. In addition, students can take part in English speech activities, learn spoken English with foreign teachers, communicate with their parents at home and so on. However, those opportunities are limited and varies vastly across different areas as the activities are heavily depended on the school curriculum designs and school funding. Also, if students attach more importance to oral English learning, they will purposefully try their best to create an environment for themselves to practice as much as possible. However, as stated before, Chinese students do not usually consider oral English as useful in the future so most of them are not likely to create an English speaking environment for themselves.

\section{SOLUTIONS}

\subsection{Teachers' Teaching Methods}

In view of the above problems, the author summarizes some adjustments that teachers could take to potentially address the problems. These adjustments are mainly aimed at three problems in teaching.

According to Wang's study, teachers should improve their oral English teaching level and schools should pay attention to the improvement of teachers' oral English level and implement some effective methods [10]. What's more, English teachers in middle school need to insist on teaching in English to create a better oral environment for students and strengthen their influences on students so as to set an example for them. Furthermore, according to the actual level of students and the actual needs of teaching, teachers need to creatively adjust the teaching content of pronunciation in class, and do a good job in the connection between junior middle school and primary school. The teaching of phonetic symbols plays an extremely important role in English teaching. Only by learning phonetic symbols well can students lay a solid foundation for future English learning. [11, 12].

From my perspective, teachers are also supposed to encourage students to speak English and hold more English-related activities or add oral English courses 
carried out by foreign teachers in areas where the conditions permit, so as to increase children's immersion and enhance their interest and confidence.

\subsection{Teachers' Supports on Students}

The conclusion of the present study mainly focuses on the guidance of teachers to students. Zhang and Wang hold that in oral practice, we should try our best to create a relaxed environment for students and guide them to actively participate in class activities to reduce their anxiety, and improve students' confidence in communicating in English. For example, teachers can restore the relaxed daily environment through group activities in cooperation, and the use of multimedia can stimulate students' interest so as to eliminate students' anxiety and increase their chances of language output so as to better acquire language.

Moreover, teachers should often encourage students in the process of teaching, and pay attention to the objectivity and richness of language in evaluation. For example, they should be good at discovering students' advantages and give sincere affirmation and encouragement. Instead of directly denying students' shortcomings, they should point out the improvement direction and give specific and feasible methods. For example: You really did a good job and you can do better by read it more fluently.

\subsection{Suggestions for Future Development}

Personally speaking, it is not feasible to rely on the power of teachers alone to solve the problem of oral English teaching in middle school. The cooperation of parents, students and the government will have a great promotion effect in addition to teachers' teaching.

First of all, parents play an important role in facilitating their children's learning by providing supportive environment. Thus, parents should provide more supportive English context for their children to be able to practice their oral English. They should also help educate their children to help them realize the importance of oral English in their future academic and career development.

In addition, government should strengthen its guidance on students in the formulation of policies. The government should popularize the oral English test as soon as possible, and improve the importance of oral English to teachers, students and parents.

Most importantly, students should pay attention to the practices of oral English because English is a language that is a tool for communication. The ultimate purpose of learning a foreign language is to be able to effectively communicate with more people around the world. Thus, it is useless or meaningless if students learn English but cannot communicate in English. They should consciously improve the motivation to practice oral English, take the initiative to find and create an oral English environment conducive to their practice and develop the habit of speaking English at any time so as to be able to express themselves confidently. For example, when watching English movies at home, they can try to follow and practice and memorize more pronunciation rules and methods. For example, they can also take part in English speech contests and English activities as much as possible.

\section{CONCLUSION}

This review analysed the main problems that exist in middle school oral English teaching in China and the solutions to solve these problems. The problems are listed in three aspects: (1) teachers' teaching skills and oral English proficiency; (2) students' awareness and confidence in oral English; and (3) speaking environment. In addition, solutions are also listed in this review: teachers should improve their oral English and teaching skills as well as encourage students and provide more opportunities to practice their speaking English more frequently. Most importantly, suggestions for future development are also provided in this review to shed lights on governments, schools and parents on how to improve middle school students' oral English proficiency to meet the challenges which were brought by the economic globalization.

\section{REFERENCES}

[1] Zhou, J. (2021). Research on the Problems and Improvement Strategies in Oral English Teaching in Junior Middle Schools. (eds.) The 2021 Paper Collection of the South China Education Informationization Research and Experience Exchange Conference (1) (pp.715-716).

[2] Yu, Y. (2019). Problems in and Solutions to Oral English Teaching in Rural Middle School-A Case Study in ZhaoCheng Middle School. Journal of Language Teaching and Research, 10(2), 372-382.

[3] C. Baier, J-P. Katoen, Principles of Model Checking, MIT Press, 2008.

[4] Zhang, F. (2018). Problems and Countermeasures in English Listening and Speaking Teaching in Junior High Schools. Educational Theory and Practice (35), 61-62. doi:CNKI:SUN:JYLL.0.2018-35-021.

[5] Zhou, H. (2009). Strategies and Methods of Oral English Teaching in Junior Middle Schools. Foreign Language Teaching in Primary and Secondary Schools (Secondary) (11), 25-29. doi:CNKI:SUN:HXXZ.0.2009-11-006. 
[6] Song, P. (2013). Research on Problems and Countermeasures in Oral English Teaching in Junior Middle Schools. Journal of Beihua University (Social Science Edition) (01), 140-142. doi:CNKI:SUN:BHDX.0.2013-01-033.

[7] Li, J. (2018). Problems and Improvement Strategies in the Teaching of Oral English in Junior High Schools. Modern Communication (01), 90-92. doi:CNKI:SUN:XKJJ.0.2018-01-045.

[8] Zhou, P. (2020). Research on Problems and Measures in Oral English Teaching in Junior Middle Schools. (eds.) Proceedings of the 2020 Modern Educational Technology Symposium (2) (pp.190-191).

[9] Lv, J. (2014). Problems and Strategies in Oral English Teaching in Junior High Schools. English for Middle School Students (Junior High School Edition) (17), 21. doi:CNKI:SUN:ZXSY.0.201417-019.

[10] Wang, L., \& Gou, W. (2015, June). Problems Analysis and Solutions of Oral English teaching in Vocational Colleges. In 2015 International Conference on Management, Education, Information and Control (pp. 426-430). Atlantis Press.

[11] Bu, W. (2018). Research on Problems and Countermeasures in Oral English Teaching in Junior Middle Schools. New Curriculum (Part 2) (03), 7. doi:CNKI:SUN:XKCS.0.2018-03-219.

[12] Chen, H. (2014). Research on Problems and Countermeasures in Oral English Teaching in Junior Middle Schools. Xuezhou Magazine (13), 63-64. doi:10.16657/j.cnki.issn16739132.2014.13.018. 